\title{
The Creation of Transnational Memory Spaces: Professionalization and Commercialization
}

\author{
Annika Björkdahl ${ }^{1} \cdot$ Stefanie Kappler ${ }^{2}$
}

Published online: 9 July 2019

(C) The Author(s) 2019

\begin{abstract}
In the age of globalization, local memories of past violence are often dislocated from their material places as remembrance is transpiring in transnational memory spaces. Historical events and commemorative memory practices increasingly transcend national boundaries and change the way memories of historical violence, atrocity, and genocide are represented in the transnational memoryscape. This article explores how the professionalization and commercialization of museums and memorials of genocide and crimes against humanity are modes of "making the past present" and "the local global". Furthermore, professionalization and commercialization are processes through which local memories are translated into global discourses that are comprehensible to and recognizable by a global audience. In this article, we disentangle local memory places (understood as material, physical sites) from transnational memory spaces (understood as immaterial, ideational spaces) in order to investigate the transformation of local places of memory into transnational spaces of memory. At the same time, we show that, while these processes are often understood interchangeably, professionalization and commercialization are separate mechanisms and tend to be used strategically to translate memory discourses to specific audiences. These two processes can be seen as producing a standardized memorial site and a homogenization of memory in the transnational memory space. The article illustrates this theoretical reasoning with empirical findings from fieldwork in South Africa, where we zoom in on Robben Island outside Cape Town, and Bosnia-Herzegovina, where we focus on the Galerija 11/07/95 in Sarajevo, which commemorates the atrocities committed in Srebrenica in 1995.
\end{abstract}

Keywords Memory spaces - Legacy of conflict - Transformation of local places into global spaces · Robben Island · Srebrenica

This article has been written as part of a larger research project on Cultural Heritage of Conflict: Peacebuilding and the Politics of Memory, funded by the Swedish Research Council for 2018-2020.

Annika Björkdahl

annika.bjorkdahl@svet.lu.se

Stefanie Kappler

stefanie.kappler@durham.ac.uk

1 Department of Political Science, Lund University, Lund, Sweden

2 School of Government and International Affairs, Durham University, Durham, UK 


\section{Introduction}

In the age of globalization, local memories of past violence are increasingly dislocated from their material places, as remembrance is being shifted to transnational memory spaces. Historical events and commemorative memory practices transcend national boundaries and change the way memories of historical violence, atrocity, and genocide are represented in the transnational memoryscape. This article explores how the professionalization and commercialization of museums and memorials of genocide and crimes against humanity are modes of "making the past present" and "the local global." They do so by translating local memories into global ${ }^{1}$ discourses that are comprehensible to and recognizable by a global audience. Local memories of violence are located in particular places, and this article probes how these places are changed into transnational memory spaces through processes of professionalization and commercialization. In so doing, we disentangle local memory places (understood as material, physical sites) from transnational memory spaces (understood as immaterial, ideational spaces) in order to investigate the transformation of local places of memory into transnational spaces of memory. At the same time, we show that, while these processes are often understood interchangeably, professionalization and commercialization are separate mechanisms and tend to be used strategically to translate memory discourses to specific global audiences. We therefore find that these processes work as translation mechanisms between sites and audiences on a transnational level. Collectively as well as individually, they constitute and speak to a moral discourse of "never again" on the one hand and "dark tourism" on the other hand. The article illustrates this theoretical reasoning with empirical findings from fieldwork in South Africa, where we zoom in on Robben Island outside Cape Town, and Bosnia-Herzegovina, where we focus on the Galerija 11/07/95 in Sarajevo, which commemorates the atrocities committed in Srebrenica in 1995. In this, while we do not deny the agency, neither of the memory-makers nor the spectators or consumers of heritage, we focus specifically on the translation of heritage discourses to speak to global audiences. Having previously focused on the agents who drive such processes (Björkdahl and Kappler 2017), we here turn to investigate the mechanisms of the processes themselves, acknowledging that, in most cases, the commercialization and professionalization of memory sites is not the mere result of the decision of a set of mnemonic actors but corresponds to a global economy in which memorymakers and consumers interact politically, socially, and financially. Such dynamics are therefore not mono-directional but represent a complex interplay of "uploading" and "downloading" both discourses and economic assets.

We take as our point of departure the notion of "reflexive comparison" in the sense of a multi-site ethnography to demonstrate the contested politics of memory (Marcus 1995; Hannerz 2003; Gupta 1997). The reflexive approach recognizes that, while knowledge is context-bound, cases "speak to each other" and that an analysis of the different circumstances can move beyond the particularities of each case to find commonalities and generate theoretical insights (Gingrich and Fox 2002). Our choice of multi-sited ethnography is derived from the inter-disciplinary work we undertake to read memoryscapes in conflict-affected societies. When discussing methods of research inquiry, this article singles out diagnostic sites of analysis, such as local places of commemoration, which, in our analysis, are memorial sites that hold in place collective memories of traumatic memories. They share a transnational

\footnotetext{
${ }^{1}$ In this article, we refer to "transnational" as a process that involves more than a domestic dimension, while we use "global" to refer to a different scale of analysis.
} 
dimension of local and global memory cultures. These diagnostic sites speak to globalized memory discourses, creating an imaginary shared space, and their functions can be read through the ways in which they are professionalized and/or commercialized (or not). To investigate the two sites, we have "been in place", i.e., we conducted participatory observations, watching and listening to staff and visitors, and conducted spatial readings of the particular local memory places. Through an analysis of the narrated memories presented in these places as well as their presence in the virtual world through websites and visitor reviews of the local memory sites, we have been able to expose processes of professionalization and commercialization that transform these places into transnational spaces. Through multiple visits to our diagnostic sites, we were ourselves part of the transnationalization of memory and carriers of memories as well as transmitters of other people's memories through our writings and publications. Our reading of those memorial sites as presented in this article is therefore not only a methodology but also an ontological indication of how memory travels across local, national, and global communities.

Our first empirical illustration, the Robben Island Museum near Cape Town, is dedicated to the commemoration of the anti-apartheid struggle, associated with the prison island on which political prisoners (including Nelson Mandela) were held by the apartheid government. It now serves as a tourist magnet through the tours provided to visitors by former prison inmates. While raising considerable income through ticket sales alone, there are now new projects that act as commercial off-springs to the heritage site itself, yet all reducing the island's complex and multi-layered history to the layer of the anti-apartheid struggle. It is one of South Africa's main tourist attractions and has doubled its visitors to the island between 2014 and 2015 (IOL 2016).

The second transnational memory space we investigate is the Sarajevo-based Galerija 11/ 07/95, which opened in 2012 and commemorates the genocide that took place in the Potočari area of Srebrenica in 1995. The massacre has been globally marked as the most violent event of the Bosnian war and "the worst European genocide since the Holocaust of WWII" (Jacobs 2016). The permanent exhibition of the Galerija aims to preserve the memory of the Srebrenica tragedy through videos, photographs, and interactive documentaries to make the spectators reflect on the particular politics of remembering and forgetting. Together with web-based mnemonic material, it reflects a move towards what we call "satellite commemoration," that is, an attempt to bring the memorial site closer to its spectators when the latter do not come to the "authentic" site itself.

Both sites that we analyze in this article represent key sites that serve as platforms on which local memories can be communicated to global audiences, mainly in the form of dark tourism. Both can be read in a context in which there is a high degree of transnational mobility that allows for increased traveling, linked to the presence of tourist interest in the heritage of war and disaster (cf. Hartmann 2014). Both sites share a target audience which is predominantly global in nature. Robben Island and the Galerija tie in with a global narrative that links to a warning "never again". They are testimonies to past violence and represent an attempt to communicate the suffering of a particular community to a wider political context. Finally, as we will show below, both sites have become part and parcel of a wider transitional justice process during the course of which transnational recognition of the suffering that has taken place is important to their operators.

Through an analysis of processes of commercialization and professionalization of memory places at these diagnostic sites, we show how certain mechanisms serve to cater to a global audience and tie in with global discourses on the one hand, but also lead to the homogenization of mnemonic variety on the other hand. 


\section{Transnational Memory Spaces and Traveling Memory}

Memory studies have moved beyond methodological nationalism. As pointed out by De Cesari and Rigney (2014: 2), time-space compression, virtual and digital technologies, global communications, post-coloniality, transnational capitalism, and migration mean that a new a post-national awareness is emerging and, in the wake of the various processes of globalization, memories become increasingly trans-scalar. Memory scholars call for "nation-transcending idioms" (Levy and Sznaider 2002: 88) and "new grammars of memory" (Assmann and Conrad 2010) to help unpack the collective memory concept, which has been firmly embedded within the "container of the nation-state" (Levy and Sznaider 2002: 88). Global memory, cosmopolitan memory, and transcultural memory are new terms that have emerged to describe these mnemonic phenomena that transcend scale (Levy and Sznaider 2002; Crownshaw 2011). The research by De Cesari and Rigney (2014) responds to this challenge as it focuses on the circulation, articulation, and scales, where articulation and circulation can be understood as processes that allow memory to transcend scales. Investigating place and space more in detail, Kennedy (2014) examines the processes of deterritorialization and reterritorialization of memory. Astrid Erll's work (2011: 9) on traveling memory reveals the need to critically explore sites of memory and open up the discussion to manifestations of transnational memory that unfolds "across and beyond cultures". Such perspectives force us to rethink our ontology of memory and the spatial units of analysis (Vertovec 2009; De Cesari and Rigney 2014). In her work, Erll (2011) maps five dimensions of traveling memory: carriers, media, content, commemoration practices, and mnemonic forms. The first are the carriers of memory, i.e., the individuals who share collective images and narratives of the past, who remember, and take part in memorialization. Thus, travelers, tourists, migrants, and diaspora are key carriers of memory, turning local memories into transnational memories (cf. Appadurai 1996). In her study on dark tourism, Wendy Wiedenhoft Murphy (2010) finds that tourists have had a crucial impact on the dissemination of memory discourses transnationally and on the transformation of memorial sites, particular sites of mass atrocities, genocide, war, and battles. A second dimension reveals how the content of memory travels through media and how media technologies are used in remembrance (Erll 2011). The role of the media is also stressed in the work of Tellidis and Kappler (2016) who demonstrate the importance of the emergence of new technologies for transforming memoryscapes. The third dimension refers to the content of memory and how it travels through shared images and narratives. Erll (2011: 13) gives the example of apartheid as a "prime example of mnemonic content with a virtually global reach". As this mnemonic content has been uploaded and become transnational, it has also been downloaded and appropriated by local places around the world. Fourth, commemoration practices are additional means of memory travel. The final way that memories travel is through the symbols of mnemonic forms (Erll 2011). Travel, migration and media, and various forms of diaspora lead to the diffusion of memories, processes of memorialization as well as forms and practices of remembrance across the globe. The manner in which a society recalls the past relates to actions such as reiterations of the past, the storing of memories, the retrieval of past events, the transmission of narratives of the past, reinterpretations of and knowledge about the past, not only locally, but also transnationally. Our approach adds to the process-oriented understandings of transformation of local memories into transnational mnemonic phenomena.

In the post-conflict memory landscape, we understand memory politics as being held in place by local sites that constitute the material legacy of the conflict and, in a dialectic manner, memory politics put the local memory sites in their place. In this sense, memorials exist in the 
present to tell us something about the past while seeking to affect the future. Memorials and museums are embedded in local sites, and they function as nodes around which the fabric of remembrance unfolds in multifaceted and organic ways. Some are sites where the atrocities occurred, others are constructed and represent more abstract and conceptual sites, and they can be placed anywhere (Barsalou 2014). Memorials are often seen as established for the construction of collective memories, meaning, and identities. At memorial sites themselves, memories of the difficult past are symbolically enacted and recounted. At the same time, this symbolism is not limited to the geographical place of the memorial site itself. Through various processes and by various agents, these local memories and memorial sites are transformed into transnational spaces. To disentangle this process of transformation, we now turn to analytically differentiate between "local places of memory" and "transnational spaces of memory", drawing on our earlier work on spatial transformation (Björkdahl and Kappler 2017).

\section{Local Places of Memory}

Place is seen as a "material" form, created by people's activities (cf. Björkdahl and Kappler 2017). Place has physicality, and processes pertaining to the construction of memorial sites happen through the material forms people build or use. Place represents a distinctive, more or less "bounded" form of space, often constructed and defined in the lived experience of people. As such, place is fundamental in expressing a sense of belonging and is seen to provide a locus of identity. Looking at the world as a world of places, we see attachments and connections between people and place. According to Gieryn (2000: 465), places are "doubly constructed" as they are both built or physically carved out, and interpreted, narrated, named, understood, and imagined. Thus, place always encompasses a material dimension as well as emplacing and mediating constructions of memory artifacts and memory-making activities. The study of collective memory tends to consider shared memories as being emplaced through the memory work of nations or (ethnic) communities. The question then is whether events, such as the massacre in Srebrenica-Potočari, can be remembered and memorialized outside the ethnic or national boundaries of the Bosniak victims and the Serb perpetrators? How can the imprisonment of political prisoners on Robben Island be understood as a phenomenon of global interest and relevance?

\section{Transnational Spaces of Memory}

We frame space as the imaginary counter-side of material place, as the ideational extension of physical presence (cf. Björkdahl and Kappler 2017). Spaces are always embedded in the sociopolitical realm, not only as "product of interrelations" (Massey 2005: 9), but also as the initiating platform on which social relations can form and develop. This collective phenomenon is what Tuan (1979: 403) labels "group experiential space" and illustrates the social nature of space. Given that it refers to the meanings created in any given context, "space" only makes sense in a social environment and can only ever be understood in relation and connection to the socio-political surroundings as it represents the symbolic counter-part to physical place and thus transcends the immediate locality of a memory site. We understand transnational memory spaces to challenge the conventional understanding that memory, community, and geographical proximity are inseparable. In the sense of understanding memory as a "translocal" phenomenon, we take an interest in "the emergence of multidirectional and overlapping networks that facilitate the circulation of people, resources, practices and 
ideas" (Greiner and Sakdapolrak 2013: 375). Memory is therefore not just either locally bound or transnationally consumed, but is situated at the intersection between the two. We therefore focus on spatial transformation as a process situated geographically and historically, that is, in space and time (cf. Massey 1994: 265) in order to understand space as dynamic, not static.

\section{Transforming and Translating Local Memory Places into Transnational Spaces of Memory}

As we suggest above, it has become increasingly important for local communities to find acknowledgment for suffering not only in their immediate local context but also globally. The translation of meanings from a local to a global context, that is, between different discursive spaces, is a key mechanism to achieve this goal (Kappler 2014: 46). Coombes (1999: 639) suggests that the act of translation allows for transformation. At the same time, the translation of local sites of commemoration into transnational memory discourses also brings with it a degree of selectiveness. It involves a smoothing out of a clear distinction between victims and perpetrators, which can risk combing over the nuances and inconsistencies that are inherent in complex histories. It also means that, in many cases, an episode of suffering is stylized out of its context to make it comparable to a transnational event or site. This can then be seen as producing a homogenization of memory in the transnational memory space, that is, an ambition to speak to an audience beyond its immediate geographical boundaries. In that sense, we have to read translated memory discourses not only through a moral "never again!"-lens, but also in a strategic light. In the field of dark tourism and the associated income-generation ambitions as well as in seeking global attention, as it is the case in both the case of Robben Island and the Galerija 11/07/95, these are certainly aspects that co-shape the ways in which the mechanisms of translation take place.

These processes must also be seen in the light of claims to authenticity, which is an essential element in terms of being able to speak to a global audience that is often keen to experience "authentic" history. The provision of a seemingly "authentic" past has thus become part and parcel of the global tourism industry, often focused around a particular market-inspired theme (Chhabra 2008: 429). Particularly in contexts of "extreme historical events," including mass violence, the quest for authenticity has become a key aspect in audiences' understanding of testimonies and corresponding public histories (Jones 2017: 136). Authenticity denotes an alleged presence of the past, lending credibility not only to "authentic narratives" but also to material artifacts that are deemed unchanged and close to the experience of violence, in our case studies. It creates the illusion of a certain degree of immediacy - a "mediated immediacy"- often reinforced through the use of audio-visual material (Jones 2017: 142ff.). However, as Saupe (2012) notes, we cannot assume authenticity as a feature innate in certain artifacts of narratives per se, but instead, we have to understand it as a communicative practice. Hence, assuming that authenticity is the result of process of social construction, we might be better off talking about "authentication" to denote the processes through which publicly credible histories are constantly (re-)created and (re-)enacted (cf. Peterson 2005). In that sense, the professionalization and commercialization of heritage sites do not exclusively denote processes of modernization of memory, but they can instead also include deliberate decisions to (re-)authenticate memory sites as a way of connecting to a global audience who may seek "authenticity" as part of a wider tourist experience (Martin 2010: 538).

Hence, there are various ways in which localized memory sites "places" can be transformed into global memory "spaces" that engage participants beyond the immediate surrounding communities (cf. Björkdahl and Kappler 2017). In many cases, the act of translating between 
different memory communities and transforming a memory site in this light is done by means of commercialization and professionalization as a way of letting memory sites speak to a transnational audience. ${ }^{2}$ Turning a memory site into a tourist attraction can raise ethical issues of the exploitation of trauma on the one hand, but it can also provide a space of dialog between those who have experienced trauma and those who are encountering it from an outsider perspective. Especially in societies that have undergone massive degrees of violence, the trauma experienced is never accessible to those who did not directly experience it themselves. They can never relive the pain of those who underwent war and violence. This is the context in which we can understand the professionalization of memory as an act of conditioning and processing memories of violence in order to make them, at least partly, accessible to outsiders. The professionalizat of memory narratives in combination with demands from a global audience to familiar story lines produce a homogenized outcome in terms of a global, collective memory. This is often, but not necessarily, linked with profit-driven ambitions and a drive to commercialize as well - either to sustain the memory site itself and prevent it from decay or to generate profit for its different stakeholders. This in itself raises a number of ethical issues, as we will discuss below.

\section{Professionalization}

Professionalization is about managing and re-framing traumatic collective memory for a global audience. In much of the existing literature on professionalized heritage, the ideal of "professionalization" itself is an actor-centered one, that is, an approach that focuses on the role of trained specialists and experts in terms of promoting and authorizing memory artifacts (cf. Gentry 2013: 509; Smith 2006; Waterton and Smith 2010). Yet, assuming that professionalization is not merely a matter of staff training nor exclusively a decision to develop a certain quality within the actors involved, but instead a quality that can refer to the process of presenting heritage, we follow the approach of Wadensjö et al. (2004) in suggesting that professionalization is to be read as the way in which heritage communicates with its audiences. A second dimension of professionalization is place-bound and refers to the improved material, technological, and communication standards of the site, the ease through which the visitors can access the complex narrative of the past, the improved flow of movement at and within the site. In that sense, the local memory place is shifted from a lay approach to a professional approach in communicating collective living memory to global audiences. In this article, therefore, we investigate professionalization of sites as processes that improve the access to and visibility of heritage to global audiences, in an attempt to connect memory artifacts with "unlikely audiences." This can be achieved through various means, including the re-framing to help interpret the past, use of new technologies, and means of communication such as virtual and online media or claims to spatial authenticity, which we illustrate below. In that sense, while we do not deny that diverse agents drive such processes, in this article, we are particularly interested in the ways in which the latter are driven by the complex interplay between global normative and economic structures as well as audience demands. The process is therefore no longer fully controlled by memory entrepreneurs but necessarily co-shaped by global structures and audiences and must therefore not be reduced to the role of those initiating it. A focus

\footnotetext{
${ }^{2}$ This article does not include an analysis of the audience or the tourists that interact with the memory places and transnational memory spaces. For a relevant case study, see Wiedenhoft Murphy (2010).
} 
on process rather than actors then allows us to account for this interplay between actors and structures in the transformation of place.

Even though memorials have been around for a long time, they are becoming globalized as memories are shared and unbound. Thus, they increasingly focus on audience attraction. New emphasis is placed on memorial site-audience interactions and relationships. To facilitate the communication of memory, a single and familiar story line will be the most likely way of addressing memory audiences. This change in purpose and priorities of memorials has impacted the nature of collective memory. The recognition of memorials' appeals to differentiated audiences has often brought about a professionalization of the memory artifacts and a commodification of the memorial. In many ways, the symbolic meaning and the aesthetic experience they inspire present the spectator with the moral imperative of "never again" and with embodied arguments regarding civic duty and responsibility and a reasoning during which the visitor can assess the political significance of the memorial (Sci 2009). In that vein, we can witness memorial museums increasingly shying away from text and photographic exhibitions only, towards an interactive approach that pursues a multisensory approach to the visitor. The latter is invited to become part of the experience in a multiplicity of ways. The Apartheid Museum in Johannesburg, for instance, provides the visitor with a ticket that ascribes her/him to either the "black" or "white" entrance to the building, and therefore attempts to engage museum guests to a more active experience of the past. In a similar vein, the "Cradle of Humankind" museum between Johannesburg and Pretoria includes a boat ride and is full of computer-animated technology in its ambition to point to a very different kind of memory - that of the origin of humankind itself.

\section{Commercialization}

To what extent are memories and memorials turned into commodities? There is a global trend of turning collective memories of gruesome pasts into a tourist product. Through branding and marketing, places associated with a difficult and traumatic past are "packaged, promoted, priced and positioned" (Brown et al. 2012: 198) to attract a diverse global audience. In this way, tourists both get to understand and "relive" the past as a key tourist experience. This commodification of memory, museums, memorials, and narratives commemorating the past challenges conventional understandings and uses of memorials as authentic sites where past events happened, of honoring the dead and of personal mourning, and becomes particularly troublesome when speaking of living memories. This can be done merely in order to maintain a particular site in the absence of public funding. It can, however, also be a way of generating income for the profit of those running the memorial site. Here, Baillie et al. (2010) point to both negative and positive consequences of heritage commodification, while Jethro (2018) reflects on the contested nature of such processes, which have long been subject to criticism on the part of a variety of actors.

In a context such as South Africa, where a large number of memorabilia are held in private hands, ensuring public access to the legacy of the nation is a serious concern. It also empowers memory entrepreneurs who can afford to buy up artifacts of historical significance and significantly impacts the extent to which the memory landscape becomes fragmented and concentrated on public resources. Whether an archive, as important it may be, can host and display memory resources, indeed largely depends on its ability to purchase memorabilia from private owners. 


\section{Homogenization}

Both processes of commercialization and professionalization can contribute to the global homogenization of memorials and memory narratives as they tend to address an assumed generic global spectator or tourist. Moreover, the commercialization and professionalization of memorials not only works to promote a certain reading of the past but also to homogenize the very memory of the past in order for the particular, local memory discourse to speak to a universal, global discourse. Through these two processes, a level of standardization of memorials has been established in relation to themes of trauma and atrocity which has contributed to the homogenization of memorial aesthetics and commemoration practices that facilitate the transformation of local memory places into transitional memory spaces (cf. Bavidge 2012; Buckley-Zistel 2014; Erll 2011). Baer and Sznaider (2015) remind us that the universalization of the "never again" discourse originates from the significance of the Holocaust memory and its transnational communication (pp.332), transcending "the communities, nations, or groups involved in the events as victims, bystanders, or persecutors" (p.331).

Hernàndez i Martí (2006), too, reflects on the extent to which deterritorialization and reterritorialization go hand in hand, in the sense that sites of cultural heritage in a globalized world strive to differentiate themselves from each other on the one hand. On the other hand, global memories also have to sit in a homogenized discursive space in which their messages are translatable beyond their immediate geographic territory. Hence, if we speak of "homogenization" in this article, we do not mean that the actual sites adapt to each other in terms of their specific, local history. However, what we point to is their tendency to connect to a wider global discourse, using similar languages and marketing patterns that appeal to an imagined deterritorialized audience. Such processes, which Hernàndez i Martí (2006) refers to as "heritage hybridization" are facilitated through the presence of global institutions such as UNESCO, civil society actors, and mass media. Thus, homogenization could be seen as a part of touristimication (Salazar 2009). We therefore agree with Baer and Sznaider (2015) that universal memories do not replace particular memories but instead continuously interact with each other (p.332). However, what this shows is that the professionalization and commercialization of local memory places into transnational spaces may primarily affect their transnational presentation, however at the same time informing and interacting with the ways in which local places "download" from those very universal discourses. If one changes, so does the other. Transnational memory must therefore not be considered in isolation of local memory, but in constant, mutual interaction. The extent to which memories need to translate into transnationally comprehensible discourses, often by resorting to iconic visual representations (cf. Brink 2000: 144), not only affects their homogenization on a transnational, but also, perhaps less so, local level.

With this in mind, we now go on to focus on Robben Island and the Galerija 11/07/95 as two very different mnemonic sites, which, however, make clear statements in terms of aiming to tie in with the transnational discourse of never again while relying on techniques of professionalization and commercialization. We will show that the choice of strategy in terms of transnationalizing their messages differ considerably, yet have, in both cases, led to a degree of homogenization of the memory discourse. While these sites continue to emphasize their local and contextual specificities, they have nevertheless had to resort to a globally understandable, almost iconic, language and a certain degree of simplification of their narratives in order to reach out to transnational audiences. Strategies of professionalization and commercialization are thus part and parcel of an attempt to make the memorial sites financially sustainable and globally relevant. 


\section{A Transnational Memoryspace: Robben Island}

One globally known transnational memory space is Robben Island, located a short ferry-ride from Cape Town in South Africa, and one of the main tourist attractions in the area. Visitors are taken to the island by ferry and then given an approximately 2-h-long tour of the former prison site in which the apartheid government had held its prisoners. The island is also a UNESCO World Heritage Site and hosts a museum that tourists can visit. In December 2016 alone, almost 50,000 visitors took the ferry to the island, with an increasing proportion of domestic visitors as well (Traveller24 2017). Ticketholders will normally board a ferry and then spend a couple of hours on the island, albeit not on their own, but instead with a guided tour by a former prisoner of the Robben Island prison. The fact that Nelson Mandela received the Nobel Peace Prize in 1993 certainly helped connect him to a transnational audience and is therefore a standard attraction for the tourists who come to Cape Town. Meanwhile, tickets are often sold out online days before (although several trips per day are offered).

\section{The Local Place}

Despite the complex heritage of the island (including histories of the use of the island by indigenous people, its use as a leprosy colony, foreign occupation, or the Second World War (cf. Björkdahl and Kappler 2017), the main emphasis presented to the tourists is on the prison site and, within that, Nelson Mandela's story of being a long-term prisoner on the island. This comes as no surprise against the background that Mandela is globally regarded as a hero in his fight against racism (Gertner and Kotler 2004: 54). In this vein, the focus on Mandela partly arises out of a strong tourist interest in his story as much as to the legitimization of the current government (as the successor government to Mandela) to the outside world.

What is interesting to note is that, after having been transformed into "Robben Island Museum," the heritage site very much represents a government-driven approach to reconciliation. Despite the different layers of unknown histories that can be found on the island, the full potential of the island - tourist or otherwise - is not really being tapped (personal interview, anonymous source, Johannesburg, 21/11/17). Instead, the island represents a powerful yet partly scripted narrative of the liberation struggle led by Nelson Mandela and therefore grounds its identity strongly on this historical aspect, mainly in relation to the process of nation-wide reconciliation (Strange and Kempa 2003: 394) and human rights (Deacon 2004: $312,313)$. More details of the locally specific and multi-layered history of Robben Island, including the stories of the wives who visited their husbands on Robben Island, are to be found in the Jetty 1 Museum at the V\&A Waterfront. Yet interestingly, this small museum is much less known by the tourists and is therefore not frequented in any comparable way to the prison itself.

\section{A Transnational Memory Space}

Much of Robben Island's political and economic capital lies in its interconnectedness with the story of Nelson Mandela, who is globally heralded as a hero. Interestingly, Robben Island is not the only prison site that has turned into a tourist attraction or a political site indeed. Strange and Kempa (2003), for instance, draw parallels between the dark tourism experience that connects both Alcatraz and Robben Island. There is equally a growing scholarly interest in Northern Ireland's Maze/Long Kesh prison (Björkdahl and Kappler 2017; Flynn 2011). Such 
sites become embedded in a global narrative of political imprisonment and the associated injustices in a state and/or justice system that led to their erection. In that vein, the Prison Memory Archive ${ }^{3}$ that has been established in the Northern Irish context may seem to have a very strong local resonance to begin with, but it speaks to a global audience at the same time. This is mainly the case through its thematic approach - a focus on issues such as gender, heritage, religion, protests, and so forth. The prison experience can therefore be seen as a transnational one and is shared between South Africa and Northern Ireland, between the USA and Brazil, and is one that increasingly attracts "dark tourists."

The Professionalization of Robben Island We argue that the island has been professionalized only to a limited extent. Much of the former prison is still in place and displayed as a site in decay, and there is little by way of written explanation to the visitors. The visit to the prison site does not include interactive high-tech devices, but instead is primarily based on the respective guide's narrative as well as the experience of the site in itself. However, the relatively small degree of technologization of the island does not mean that it fails to translate its message to the visitors. Much in contrast, the idea of an "authentic" experience, that is, one that provides an embodied version of being imprisoned, is emphasized, and indeed popular with the visitors. This is its own way of professionalizing the memory, namely through a presentation of the museum as frozen in the past, not tinkered with and very much as if the prison had just been closed. For the tourists, this process of "authenticating" the site is a crucial incentive as it allows them to experience the site as was and to feel a certain degree of immediacy of experience during the tour.

They particularly enjoy spending time (and there is very little during what seem to be a rush of tours, one after the other) in Mandela's former prison cell—presented "as was"and getting a sense of what life on the prison island was like (field notes, August 2012 and personal interview, confidential source, Cape Town, 06 July 2018). In that sense, the modernization or mediatization of the space, in the sense of physical upgrading, would be counter-productive to the experience, as it would seem to take away from its feel of authenticity. Therefore, it is mainly the current museum website that attempts to be more interactive in terms of engaging with the different layers of history on the island and pointing to its multifaceted past. At the same time, the main point of contact, especially for transnational visitors, is the site itself rather than the website (which is instead primarily used for ticket purchases). Interestingly, the ways in which the professionalization of the site has worked has largely been in its strategic use as an educational tool (Shearing and Kempa 2004: 65), an attempt to communicate the history of the liberation struggle not only locally and nationally, but also globally. Again, this is primarily done through the tours provided rather than self-guided study or interactive tours. We suggest that the main aspect of the professionalization of the physical site itself is grounded in its claims to authenticity, that is, the sensory exposure of the visitors to the material of the place. There are now plans to adjust the narrative provided by the prisoners to make it more consistent, enhanced through the flavor of their personal stories (confidential source, personal interview, Cape Town, 03 July 2018). This, if implemented, would give additional control to the island management to be able to steer the narrative delivered-possibly to include more of the women's experience in relation to apartheid imprisonment but also at the risk of generating skepticism among the tour guides.

\footnotetext{
$\overline{{ }^{3} \text { http://prisonsmemoryarchive.com/ }}$
} 
The Commercialization of Robben Island In the context of a heavily privatized heritage sector on the one hand, and strong government ownership of the heritage related to the liberation struggle on the other hand, it comes as little surprise that Robben Island has been part of an increasing tendency of commercialization. Indeed, the fees of currently R340 (approx.. €35) are extremely pricey for the average South African who will rarely be able or want to afford a visit to Robben Island. Marketed as a "Cape Town Attraction" on the website though, a trip to the island has almost become one of the "must-sees" of Cape Town. In Cornelissen's words, it can be argued that the Robben Island Museum management has succeeded in its "place marketing" vis-à-vis tourists (Cornelissen 2005: 675). This can be considered part and parcel of South Africa's wider national economic strategy that sees tourism as a key sector of income-generation (Cornelissen 2005: 680). In that vein, the heritage site attracts funds not only from its visitors, but also from private overseas sources (Shackley 2001: 356). It is interesting to note that there have been several initiatives to further commercialize the use of the heritage site. There had been debates about the establishment of a "Centre for Conflict Resolution and Education", coupled with "the provision of overnight hotel facilities, including luxury accommodation for VIPs" (Shackley 2001: 362). Yet this initiative was not taken forward.

Instead, there are a number of projects recycling the original prison fence, which Jethro (2018) refers to as "liberated waste" in reference to the instrumental use of heritage. The fence itself had originally acted as a barrier to the prisoners of the island. In 2009, the prison fence, which "looked like any other fence," was prepared to be shipped from the island to the mainland and dumped (Jethro 2018: 261 f.). However, recognizing its heritage value, artist Christopher Swift was granted permission by the authorities to creatively upcycle the material (ibid.).

In a personal conversation on this topic, Swift suggested that, where there is no public or philanthropic funding for heritage work, there is a need to commercialize in order to preserve (personal interview, 02 July 2018). Swift has developed a number of artworks with the remnants of the fence in order "to get the positive out of the negative", as he suggests (ibid.). Moreover, and this illustrates the interconnectedness of the up- and downloading of memory between local places and global spaces, Swift states that the international attention he has received for his artwork has helped him restore its value at a domestic level (ibid.).

Linked to Swift's work with the fence is a jewelry designer who uses the fence to produce high-end jewelry. Jethro (2018) problematizes the so-called "Legacy Collection" that uses parts of the original prison fence to produce and sell items entitled "Redemption Bracelet", "Free Will Pendant," or "Amandla Cufflinks" ("Amandla" being a key expression in the Liberation Struggle and translating as "Power"). This example speaks to the overall processes through which heritage is embedded in privatization policies that South Africa is known for and which, among others, represent a threat to the preservation of cultural heritage and memory sites. At the same time, the "souvenirs" being fabricated from the prison fence do attract a transnational audience - which is not least evident through its retail partners, most of which are South African high-end hotels as well as a retailer based in the USA. At the same time, this is not radically different from the earlier days of when the museum had just opened. Davison (1998) suggests that even then, "[s]igns of tourism development to follow were [...] present in the local shop: Robben Island T-shirts, souvenir teaspoons, and bottles of wine, successfully marketed as Robben Island Red" (p.157). In that very same timeframe, the attempted use of the label "The Original Robben Island Trading Store" was not welcomed by the former prisoners either, to put it mildly (ibid.). Again, the proposed use of the notion of originality points to the ambition to sell a degree of authenticity to the visitors of the island, not unlike the Legacy Collection discussed above. 


\section{Transformation of the Robben Island Memorial Site into a Transnational Space of Memory}

As this example shows, the Robben Island memorial site indeed has the potential to connect between a history of apartheid, which is very specific to South Africa, and a transnational experience as it is represented through its visitors. It is particularly Nelson Mandela's story that appeals to the public, not least as it is well-known globally. It is therefore this story that equips the site with its transnational significance - much more than its history of hosting indigenous groups, acting as a military base or as a leprosy colony would do. The transnational aspect of the memory site is therefore selective, and the imaginary space of memory that emerges is very much centered on Mandela's individual story. It points to the horrors of apartheid and implicitly gives a warning to visitors to never underestimate the dangers of segregation and of a hierarchical justice system largely based on skin color.

It becomes clear that this process of translating the complex layers of local history into a transnational memory narrative around the anti-apartheid struggle tends to happen, at least partly, through its commercialization in the light of the strong tourist presence in Cape Town. In a way, the commercialization processes in conjunction with the homogenization of heritage sites brings about a less nuanced and a more black and white interpretation of the past. The reduction of the different layers of history on the island to a single one is part and parcel of the de-complexification of its history and, thus, its "unique selling point" to its visitors. Acting as a visitor attraction in Cape Town, the relatively pricey ticket fee does not deter tourists but instead ensures a "smooth" visitor experience where the visit is sold as a package, including the boat tour to the island. Additional processes of commercialization, such as the above-mentioned retailing of the former prison fence, support the transnational outlook of the site on the one hand but come with their ethical issues on the other hand. The example of Robben Island therefore reflects the extent to which the establishment and development of a transnational heritage site can be based on political and economic interests. Those can risk misusing heritage by reducing its complexity (which is often of appeal to outside visitors), while at the same time generating jobs and income - an aspect that must not be neglected either.

\section{A Transnational Memoryspace: The Galerija 11/07/95}

The largest and perhaps most renowned memorial in Bosnia-Herzegovina is the SrebrenicaPotočari Memorial Centre outside the small town of Srebrenica in Republika Srpska. It was constructed to commemorate the genocide that took place there in July 1995 when more than 8000 men and boys were killed by the Bosnian Serb forces. The memorial addresses the need to acknowledge past sufferings, rehabilitate the dignity of victims, and support personal grieving processes. The Srebrenica-Potočari Memorial Centre is mirrored by the Galerija 11/07/95, which is a museum named after the Srebrenica Memorial Day on 11 July 1995, situated in Sarajevo and open since 2012. We here focus on the Galerija as to reflect how transnational memory spaces emerge beyond the site where violence has happened. Based on this, we argue that this form of "satellite commemoration" is the result of professionalization and commercialization processes in a context where global audiences are unable or unwilling to visit the "authentic" site itself.

\section{A Local Place}

The Galerija 11/07/95 is a site representing the Srebrenica-Potočari place of memorial. As such, it is a constructed memorial site founded by the photographer Tarik Samarah, an artist 
who has lived in Sarajevo for more than 30 years. The site declares itself to be a museumgallery hybrid that blends artistic and documentary forms. The exhibition space is large and its photographic exhibition not only commemorates the events of 11 July in Srebrenica but also reflects on how the event is represented in local and global memory discourses. It intervenes in a historical moment that is not only situated in the recent past but belongs to the present as well. The storytelling of the exhibition space corresponds with the arrangement of the photographs on display along the circulation path, which constructs a more or less coherent storyline. Its aesthetics and dramaturgy are artistic, sober with black and white photography. Photographs by Tarik Samarah from the Srebrenica series offer insight into fragments of the still unresolved trauma of Srebrenica. The photographs remove any mediator between the observer and the observed, showing the emptied landscape of reality in Srebrenica. The blackand-white technique expresses the boundary between life and death and shows us a world of gray, where human brutality has replaced humanity. That narrative of the exhibition is fragmented, and it does not permit the creation of a single, well-rounded narrative. Excerpts from everyday life of the survivors, landscapes of the crime, scenes depicting discoveries of the mass graves are but a small part of the content of these photographs. One of the images exhibited at the Galerija 11/07/95 is of the half-decomposed hand of an exhumed victim held in the hand by a forensic examiner making it appear as if they are holding hands. This image is widely used on websites, in museums, and at the Potočari memorial site. Images of the Srebrenica fields of death do not allow an observer to be a passive consumer of the story; instead, they produce a witness.

\section{A Transnational Memory Space}

Given that Srebrenica is an almost 4 hour bus drive from Sarajevo, where most tourists spend time, not many of them take a trip to the Srebrenica-based Potočari memorial site. Visiting a gallery-museum in Sarajevo can, for many, be a more convenient experience to engage with the atrocities committed in Srebrenica from afar. In 2003, the exhibit of photographs by the founder of the Galerija 11/07/95, Tarik Samarah, was donated to the Memorial Centre in Potočari. They were later returned to the Galerija 11/07/95 as the first work of art to be exhibited there when it opened in 2012. The narratives on display here echo the ones at the Potočari memorial. In unison, the two memory sites act as platforms for the survivors, victims, and the relatives of victims in their repeated calls for justice and acknowledgment.

The Professionalization of the Galerija 11/07/95 The Galerija 11/07/95 is a cosmopolitan site and reflects a globalized memorial culture. It is seen by many visitors as an essential part of a visit to Sarajevo, according to comments on Tripadvisor. The English-language tour included with the entrance ticket is part of the professionalization of the site. Visitors are given a deeper understanding of each of the images on display as they get to hear the story behind it. These already moving photos are brought to another level of emotional and intellectual engagement and help create the empathy that relates to the never again discourse.

Part of the professionalization and transnationalization of the memories of genocide is a new, professional website "The Web Genocide Museum", which provides a virtual tour of the actual Potočari memorial site. It is intended for a global audience and the visitors to the website are able to go on a 360-degree virtual tour, come close to the Memorial Wall, and read the names of those who are no longer there. They may walk the stone 
paths bordering the sacred area designed as the Srebrenica flower, in the petals of which lie the remains of those killed. They can also listen to testimonies of survivors and relatives of victims - some of whom claim that justice has not been served, that the story of Srebrenica genocide has become a story of a tragedy, and that most of them fear that the genocide will be forgotten. A Facebook page is part of the professionalization process as it helps increase the accessibility of the Srebrenica narrative transnationally and keeps the memory alive with new posts that highlight annual commemorations and global and local events relating to the genocide. In addition, it contains reviews from visitors sharing their emotional response to the site.

It is through professional memory frames that the memorialization and commemoration of the Srebrenica genocide connect with genocides of the past and present as well as acting as a general warning to future generations. This becomes even more pronounced if we look at the exhibition at the Galerija 11/07/95, where the photographs taken by the founder of the gallery-museum are also part of a traveling exhibition. Tarik Samarah's photographs have been exhibited in art galleries and museums across the world. On the tenth anniversary of the fall of Srebrenica, his photographs were exhibited in the US Holocaust Memorial Museum in Washington, and subsequently displayed in the UN Headquarters in New York, in Cape Town, in Geneva, in the Dutch Parliament, in The Hague, Gallery du Jour in Paris, in the Illinois Holocaust Museum \& Education Center in Chicago, as well as many other places. In 2005, he exhibited the images of the Srebrenica massacre on large commercial billboards in several cities in Serbia, including Belgrade, Čačak, Niš, and Novi Sad. These posters carried the message: "To see, to know, to remember Srebrenica 1995-2005" and were used to raise awareness of the events that took place during the Srebrenica genocide. Samarah's photographs also appeared around the world on the covers of various books dedicated to the Srebrenica genocide, thus raising awareness of it beyond the immediate memorial site and even of Bosnia-Herzegovina.

The Commercialization of the Galerija 11/07/95 Presentations of memorial sites to tourists, according Cole (1999), can be read as an amalgamation of history. The Galerija 11/07/ 95 presents itself as a cosmopolitan site and reflects the globalized memorial culture and its commodification. On its website, the Galerija announces that donations are welcome and the website is explicit about how donations are made, including bank transfers in local and international currencies and bank account numbers. Outside the exhibition site is a souvenir shop, where tourists can buy memorabilia from the war. The ticket price is $7 €$, which is in the same price range as the other museums in Sarajevo. It is worth noting that entrance at the Potočari memorial site in Srebrenica, however, is free of charge. In many ways, the diagnostic site of the Galerija magnifies the relatively lesser degree of commercialization that is visible at the actual memorial site in Potočari, while partially relying on ticket sales for the maintenance of the exhibition space. Tarik Samarah carries the memories of the genocide by representing them in photographs that are exhibited in art galleries and museums across the world. The art is a benevolent way of commodification of the Srebrenica genocide, presenting an emotional narrative through the display of the photographs. In the commercialization process, the emotional genocide narrative becomes a tradable commodity. At the same time, the gallery-museum does not seem to be primarily about income-generation, but instead an attempt to promote the message of never again to a global audience, as we have shown above. 


\section{Transformation of the Srebrenica Memories into a Transnational Space of Memory}

The transformation of local memories into a transnational discourse often employs a common aesthetic language communicating a key message: We must not forget! Yet, memorials can never be accurate replicas of the past, but instead only offer a particular interpretation of an event, which may be contested or subject to change over time. In the case of the Galerija 11/07/ 95, the message is being brought closer to a global audience who often, when visiting BosniaHerzegovina, does not venture outside the capital city. Basing a gallery-museum in the heart of Sarajevo's old town renders the memory physically accessible to a larger pool of audiences and at the same time shifts its emphasis away from the "authentic site" itself towards a more discursive and symbolic understanding of space (cf. Kappler 2014). Still, as visitors to the Galerija 11/07/95 reveal in their reviews, they feel that, although not being to the authentic place, they become witnesses and the site of the Galerija implores them to shoulder the responsibility of never forgetting. Different from Robben Island, which benefits from the tourist flows to Cape Town, the memory of the victims of Srebrenica has to be physically shifted in order to be accessible to global audiences. It is in this light that we understand the function of the Galerija 11/07/95, its transnational audience, and presence in Sarajevo as well as the websites and Facebook page that continue to emerge as a way of digitally commemorating Srebrenica.

\section{Conclusion}

This article provided a conceptualization of the key terms local places of memory and transnational spaces of memory to cast light on the mechanisms through which local memory sites impact transnational memory discourses. Two important mechanisms driving the transformation of local places of memory into transnational spaces of memory are professionalization and commercialization, both of which are used strategically to translate memory discourses to audiences beyond their immediate local communities. The two memory spaces of interest in this article, Robben Island and the Galerija 11/07/95 as political heritage sites that stand testimony to violence and suffering, constitute and speak to a transnational moral discourse of never again but also to the commodification of memory in the form of dark tourism. In particular, both sites experience high levels of interest from all over the world. They are both marketed as prime examples of never again and embedded in a translocal discourse that warns of the dangers of segregation and division. By focusing on those two sites, we find that memory is often seen as emplaced and constituted in part through location, material form and their imaginings, while its reach transcends its immediate surrounding communities. This raises new critical questions, such as what happens then when memory is unbound.

What happens when a site, or a place, acts as a point of departure from which memory is transnationalized and developed in a discursive space much larger than the physical site of remembrance? What we find in such processes is a considerable degree of selectivity of memory, that is, a tendency to highlight a mnemonic aspect that has transnational traction. On the one hand, this can attribute meaning and acknowledgment to an otherwise little-known place and social context. On the other hand, it may mean that the interests of the transnational audience of the memory site become dominant over those of the local community from where the memory contestation emerges. The processes of professionalization and commercialization 
that we have highlighted in this article are illustrative of this dilemma: although they act as tool of translating between local and transnational audiences, they can also have deep social effects, positive and negative, ranging from the generation of income to the possible promotion of voyeurism. In that sense, the transnationalization of memory can evoke empathy and solidarity, as illustrated with the never again discourse that relies on past violence to warn of future violence, but it can also devalue the experience of the physical site itself - for instance when tourists try to "relive" the experience of suffering. The latter can be perceived as inappropriate by local communities who resist the reduction of deep trauma into a transferrable commodity. The two processes of commercialization and professionalization tend to make claims to the authenticity of the memorial site in order to reach a global audience. In this way, while marketing a place-specific, authentic mnemonic aspect, both processes contribute to the homogenization of the collective memories, speaking to a transnational memoryscape and presenting a smoothened out narrative. In different ways, the Robben Island Memorial and the Galerija 11/07/1995 have been able to translate a local narrative to tell a familiar storyline that resonates with a global audience and the local places of authenticity or representations of authenticity have been transformed into transnational memoryspaces. In this process, while retaining their place-based specificity, the two diagnostic sites of our analysis have become standardized and homogenized to the extent that they have to be understandable by and accessible to a global audience. The promotion of transnational memory spaces is therefore an important aspect to understanding any particular physical memory site, but does not come without its very specific ethical challenges, as we have demonstrated in this article.

Open Access This article is distributed under the terms of the Creative Commons Attribution 4.0 International License (http://creativecommons.org/licenses/by/4.0/), which permits unrestricted use, distribution, and reproduction in any medium, provided you give appropriate credit to the original author(s) and the source, provide a link to the Creative Commons license, and indicate if changes were made.

\section{References}

Appadurai, A. (1996). Modernity at large: cultural dimensions of globalization. Minneapolis: University of Minnesota Press.

Assmann, Aleida and Sebastian Conrad eds. (2010) Memory in a Global Age: discourses, practices and trajectories. London: Palgrave MacMillan.

Baer, A., \& Sznaider, N. (2015). Ghosts of the Holocaust in Franco's mass graves: cosmopolitan memories and the politics of "never again". Memory Studies, 8(3), 328-344.

Baillie, B., Chatzoglou, A., \& Taha, S. (2010). Packaging the past. Heritage Management, 3(1), 51-71.

Barsalou, J. M. (2014). Reflecting the fractured past: memorialisation, transitional justice and the role of the outsiders. In S. Buckley-Zistel \& S. Schäfer (Eds.), Memorials in Time of Transition. Intersentia.

Bavidge, E. (2012) The when of memory: Contemporary memorials to distant and violent pasts, International Journal of Cultural Studies 16(4): 319-334.

Björkdahl, A., \& Kappler, S. (2017). Peacebuilding and spatial transformation: peace, space and place. Abingdon and New York: Routledge.

Brink, C. (2000). Secular icons: looking at photographs from Nazi concentration camps. History and Memory, 12(1), 135-150.

Brown, S., McDonagh, P., \& Shultz, C. (2012). Dark marketing: ghost in the machine or skeleton in the cupboard? Eur Bus Rev, 24(3), 196-215.

Buckley-Zistel, S. (2014). Detained in the memorial Hohenschonhausen: heterotopias, narratives and transitions from the Stasi past in Germany. In S. Buckley-Zistel \& S. Schäfer (Eds.), Memorials in Time of Transition. Cambridge: Intersentia.

Chhabra, D. (2008). Positioning museums on an authenticity continuum. Annals of Tourism Research, 35(2), 427-447. 
Cole, T. (1999). Selling the holocaust: from Auschwitz to Schindler. London: Routledge.

Coombes, A. E. (1999). L'objet de la traduction: notes sur "l'art" et l'autonomie dans un context post-colonial. Cahiers d'Etudes Africaines, 39, 635-658.

Cornelissen, S. (2005). Producing and imaging 'place' and 'people': the political economy of South African international tourist representation. Review of International Political Economy, 12(4), 674-699.

Crownshaw, R. (2011) Transcultural memory. Special issue Parallax 17(4).

Davison, P. (1998). Museums and the reshaping of memory. In S. Nuttall \& C. Coetzee (Eds.), Negotiating the past: the making of memory in South Africa (pp. 143-160). Cape Town: Oxford University Press.

De Cesari, C., \& Rigney, A. (2014). Introduction. In C. De Cesari \& A. Rigney (Eds.), Transnational memory. Berlin: De Greuter

Deacon, H. (2004). Intangible heritage in conservation management planning: the case of Robben Island. Int $J$ Herit Stud, 10(3), 309-319.

Erll, A. (2011). Travelling memory. Parallax, 17(4), 4-18.

Flynn, M. K. (2011). Decision-making and contested heritage in Northern Ireland: the Former Maze Prison/Long Kesh. Irish Political Studies, 26(3), 383-401.

Gentry, K. (2013). History, heritage and localism. Policy Studies, 34(5-6), 508-522.

Gertner, D., \& Kotler, P. (2004). How can a place correct a negative image? Place Branding, 1(1), 50-57.

Gieryn, T. F. (2000). A space for place in sociology. Annu. Rev. Sociol., 26, 463-496.

Gingrich, R. A., \& Fox, A. G. (2002). Anthropology, by comparison. London: Routledge.

Greiner, C., \& Sakdapolrak, P. (2013). Translocality: concepts, applications and emerging research perspectives. Geogr Compass, 7, 373-384.

Gupta, A. (1997). In J. Ferguson (Ed.), Anthropological locations. Berkeley: University of California Press.

Hannerz, U. (2003). Being there... and there... and there! Reflections on multi-site ethnography. Ethnography, 42(2), 201-216.

Hartmann, R. (2014). Dark tourism, thanatourism, and dissonance in heritage tourism management: new directions in contemporary tourism research. Journal of Heritage Tourism, 9(2), 166-182.

IOL. (2016). Record numbers visit Robben Island, 7 January. Available at https://www.iol.co.za/travel/southafrica/western-cape/record-numbers-visit-robben-island-1967955. Accessed 19 July 2018.

Jacobs, J. (2016). The memorial at Srebrenica: gender and the social meanings of collective memory in BosniaHerzegovina. Mem Stud, 10(4), 423-439.

Jethro, D. (2018). Liberated waste: heritage and materiality at Robben Island and Constitution Hill, South Africa. International Journal of Heritage Studies, 25(3), 259-276.

Jones, S. (2017). Mediated immediacy: constructing authentic testimony in audio-visual media. Rethinking History, 21(2), 135-153.

Kappler, S. (2014). Local agency and peacebuilding. EU and International Engagement in Bosnia-Herzegovina, Cyprus and South Africa. Basingstoke: Palgrave.

Kennedy, R. (2014). Moving testimony: human rights, Palestinian memory and the transnational public sphere. In C. De Cesari \& A. Rigney (Eds.), Transnational Memory (pp. 51-74). Berlin: De Greuter.

Levy, D., \& Sznaider, N. (2002). Memory unbound: the Holocaust and the formation of cosmopolitan memory. European Journal of Social Theory, 5(1), 87-106.

Marcus, G. E. (1995). Ethnography in/of the world system: the emergence of multi-sited ethnography. Annual Review of Anthropology, 24, 95-117.

Hernàndez i Martí, G.-M. (2006). The deterritorialization of cultural heritage in a globalized modernity. Transfer: journal of contemporary culture, 1, 92-107.

Martin, K. (2010). Living pasts: Contested Tourism Authenticities. Annals of Tourism Research, 37(2), 537-554.

Massey, D. (1994). Space, place, and gender. Minneapolis: Minnesota University Press.

Massey, D. (2005). For space. Los Angeles, London: Sage.

Peterson, R. A. (2005). In search of authenticity. Journal of Management Studies, 42(5), 1083-1098.

Salazar, N. B. (2009). Imaged or imagined? Cultural representations and the "tourismification" of peoples and places. Cahiers d'Études Africaines, 49, 49-71.

Saupe, A. (2012). Authentizität, Version: 2.0, Docupedia-Zeitgeschichte, 22. 10.2012, URL: http://docupedia. de/zg/ (accessed 17 April 2018).

Sci, S. A. (2009). Rethinking the memorial as a place of aesthetic negotiation. Cultural Theory and Critique, $50(1), 41-57$.

Shackley, M. (2001). Potential futures for Robben Island: shrine, museum or theme park? International Journal of Heritage Studies, 7(4), 355-363.

Shearing, C., \& Kempa, M. (2004). A museum of hope: a story of Robben Island. The Annals of the American Academy of Political and Social Science, 592, 62-78.

Smith, L. (2006). Uses of heritage. London: Routledge. 
Strange, C., \& Kempa, M. (2003). Shades of dark tourism: Alcatraz and Robben Island. Annals of Tourism Research, 30(2), 386-405.

Tellidis, I., \& Kappler, S. (2016). Information and communication technologies in peacebuilding: Implications, opportunities and challenges. Cooperation and Conflict, 51(1), 75-93.

Traveller24. (2017). Locals love Robben Island again! Record tourist numbers hail in 20th year, http://www. traveller24.com/TravelPlanning/locals-love-robben-island-again-record-tourist-numbers-hail-in-20thanniversary-year-20170111 (accessed 5 December 2017).

Tuan YF. (1979) Space and Place: Humanistic Perspective. In: Gale S., Olsson G. (eds) Philosophy in Geography. Theory and Decision Library (An International Series in the Philosophy and Methodology of the Social and Behavioral Sciences), vol 20. Springer, Dordrecht.

Vertovec, S. (2009). Transnationalism. London: Routledge.

Wadensjö, C., Dimitrova, B. E., \& Nilsson, A.-L. (Eds.). (2004). The critical link 4. professionalisation of interpreting in the community. John Benjamins: Amsterdam/ Philadelphia.

Waterton, E., \& Smith, L. (2010). The recognition and misrecognition of community heritage. International Journal of Heritage Studies, 16(1-2), 4-15.

Wiedenhoft Murphy, W. A. (2010). Touring the troubles in West Belfast: building peace or reproducing conflict? Peace and Change, 35(4), 537-560.

Publisher's Note Springer Nature remains neutral with regard to jurisdictional claims in published maps and institutional affiliations. 